\title{
TESTAMENTARY DISPOSITIONS IN THE CONTEXT OF GLOBAL PANDEMIC
}

\author{
Marko Stilinović, LLM, Teaching and research assistant \\ Faculty of Law, University of Zagreb \\ Trg Republike Hrvatske 14, Zagreb, Croatia \\ marko.stilinovic@pravo.hr
}

\begin{abstract}
The outbreak and the rapid spread of global COVID-19 pandemic have put significant strains on the institutions. The need to adapt to "new normal" and contain the rapid spread of disease, while maintaining a functional society, resulted with introduction of numerous new legal mechanisms and adaptation of the existing ones. However, it seems that one area of law remains on the fringes: the regulation of wills.
\end{abstract}

Even before the start of the pandemic many authors often pointed to the fact that the current legal framework does not follow modern technological developments, but no significant attempts were made to overhaul the inheritance law. Also, once the pandemic started in its full, there were no references to introduction of extraordinary mechanisms or new legal solutions to overcome the potential difficulties in forming wills. Comparative analysis yielded no better results: although some countries (such as Austria) recently completely overhauled their regulation of inheritance law, it seems that no attempts were made to introduce new types of wills or new methods of drafting wills into their regulations.

Furthermore, following the spread of the pandemic, increasing number of potential testators find themselves unable to use traditional methods of drafting wills as they, or the authorized persons tasked with assistance and creation of wills, remain isolated from one another due to various reasons (lock-downs, isolation in case of experiencing symptoms, etc.).

Having in mind these circumstances, it is necessary to ascertain whether there is a genuine need to introduce new types of wills into existing legal framework, or to adapt the current legal framework by facilitating the communication between citizens and the institutions. Also, it is necessary to analyze whether the interpretation of the existing legal framework enables the introduction of certain facilitating mechanisms. In order to reach these goals and clarify the possibilities within the current legal framework, interpretative and comparative method are used.

Keywords: will, extraordinary will, digital will, electronic will, COVID-19 pandemic 


\section{INTRODUCTION}

The sudden appearance and rapid spread of global COVID-19 pandemic has certainly caught governments off-guard and while many quickly adapted and overcame the initial shock, gradually introducing measures in the private law ${ }^{1,2}$ aimed (primarily) at dealing with (and mitigating) the economic consequences of the pandemics, inheritance law and regulation of wills remained on fringes.

This is not surprising, however, as the inheritance law is one of the areas of private law in which changes are incremental ${ }^{3}$ and the regulation of will traces its roots in the Roman law ${ }^{4}$. Therefore, even after more than a year has passed since the start of the pandemic, intervention in inheritance law still occurs rarely ${ }^{5}$.

At the start of the pandemic, it was predicted that some issues related to the inheritance law would arise, whether they were caused by increased mortality rate of citizens, unavailability of public services (primarily related to the restricted access to public notaries and courts), or inability of citizens to move freely ${ }^{6}$. So far, it seems that catastrophic predictions related to economic consequences of the pandemics, which prompted the introduction of the most significant measures in the private law, were not fulfilled ${ }^{7}$. Likewise, significant issues in functioning

1 For a good overview of ad hoc legislation introduced by European states and the consequences of the pandemic - see: [https://www.intersentiaonline.com/bundle/coronavirus-and-the], Accessed 12 April 2021.

2 For example, implementation of stay on enforcement proceedings over accounts of physical persons (Act on Amendment of Act on Enforcement over Monetary Assets - Official Gazette No. 47/20) - For an overview of measures introduced in Croatian law - see Josipović, T., Restrictions of Fundamental Rights in Private Law Relations in the Special Legal Order, with Exceptional Regard to the Specific Circumstances Caused by the Epidemic, Central European Journal of Comparative Law, Vol. 1, No. 2, 2020, pp. $59-86$.

3 For the development of Croatian inheritance law, see: Gavella, N.; Belaj, V., Nasljedno pravo, Narodne novine, Zagreb, 2008, pp. $14-16$. It is interesting that the most significant systematic reform of the Austrian inheritance law since the introduction of ABGB occurred in 2015, two centuries after its entry into force (although there were several smaller changes in the meantime) - see: Rabl, C.; Zöchling-Jud, B. (eds): Das neue Erbrecht, MANZ'sche Verlag, Wien, 2015. See also: Sasso, I., Will formalities in the digital age: Some Comparative Remarks, Italian Law Journal, Vol. 4, No. 1, 2018, p. 169, 170.

4 Załucki, M., About the Need to Adjust the Regulations regarding the Form of Will to the Modern Requirements, European Journal of Economics, Law and Politics, Vol. 6, No. 2, 2019, p. 1, 11; Klasiček, D., $21^{\text {st }}$ century wills, Pravni Vjesnik, Vol. 35, No. 2, 2019, p. 31.

5 A notable of example of intervention is the example of the UK - see infra. 4.2.1.

6 Cf. Krätzschel, W., Die Errichtung letztwilliger Verfügungen in Corona-Zeiten, Zeitschrift für Erbrecht und Vermögensnachfolge, Heft 5, 2020, pp. 268 - 272.

7 It was expected that there will be a huge increase in the number of enforcement proceedings initiated against physical persons who will not be able to meet their due obligations, as the lockdown would cause a significant decrease in the economic activity - however, analyzing Croatian Financial Agency's (FINA) statistics, after the stay on enforcement proceedings ended (18. October 2020) at the end of 
of the procedures, which fall under the scope of inheritance law, were not identified. However, it seems that these circumstances represent a good springboard to initiate a public debate on necessity of the introduction of certain mechanisms to prevent negative consequences in the future (e.g. in the context of new similar situations - such as the appearance of a new, more dangerous corona strain) or simply to modernise the existing legal framework. Apart from that, this also seems as a good opportunity to discuss whether such new solutions could be unified on the EU level, leading to further expansion of the EU inheritance law.

This paper contains an analysis of current legal framework, on Croatian, as well as the EU level, followed by an overview of potential problematic points caused by the epidemics and the analysis of the legal solutions for these issues. Finally, it is discussed, whether there is a genuine need to introduce new types of wills or new mechanisms into the Croatian inheritance law.

\section{WILLS - CURRENT LEGAL FRAMEWORK}

\subsection{Regulation of wills in Croatia}

Currently, the legal framework for wills in Croatia is provided in the Inheritance $\mathrm{Act}^{8}$. A significant part of the legal framework closely follows the tradition of the older Inheritance Act dating back to $1955^{\circ}$. Traditionally, as in other legal systems, wills are considered formal and strictly personal legal acts. In order for the will to produce its legal effects, the testator must observe strict set of formalities. Therefore, laws regulating wills are often considered rigid and incapable of adapting to continuous and sudden social, economic and cultural changes ${ }^{10}$ - bereft of their

October, there were 247,270 persons whose bank accounts were blocked in the enforcement, which represents an increase of only $3.8 \%$ in comparison to March 2020, or $1.5 \%$ in comparison to October 2019. See - FINA, Broj ovršenika koji nemaju dovoljno sredstava na računima za otplatu duga i ukupni dug na dan 31.10.2020. i 18.11.2020., available at: [https://www.fina.hr/-/broj-ovrsenika-koji-nemaju-dovoljno-sredstava-na-racunima-za-otplatu-duga-i-ukupni-dug], Accessed 14. April 2021. Also, see Maganić, A., Gradanskopravno pravosude za vrijeme pandemije bolesti COVID-19, unpublished, Zagreb, 2021. - lecture held at Croatian Academy of Sciences and Arts, 22. January 2021.

8 Official Gazette No. 48/03, 163/03, 35/05, 127/13, 33/15, 14/19.

9 Inheritance Act, Official Gazette of the Federative People's Republic of Yugoslavia No. 20/55. After the Yugoslav Constitutional changes, inheritance laws were placed in the competence of the Federal Republics. As the Inheritance Act '55 was deemed quite successful, it was simply adopted again into the legal system of Croatia in 1971 - see Gavella; Belaj, op. cit., note 3, p. 15, 16.

One the most significant difference between the current Inheritance Act and Inheritance Act '55 regulation of wills is that there are fewer types of extraordinary wills in the current Inheritance Act (military and maritime wills are not regulated anymore as they were deemed outdated). Gavella; Belaj, op. cit., note 3, p. 137.

10 Sasso, op. cit., note 3, p. 169. 
traditional context, wills often seem archaic - however, such formalities are indeed justified - they ensure the expression of testator's true intentions and reduce the possibility of will's forgery. After all, when the will comes into effect, unlike in case of most other legal acts, it is impossible to check with the testator what was his or her true intention. One further consequence of this is that if a testator expressed his or her last will in a form not prescribed in the Inheritance Act (i.e. will is in an invalid form), it shall still produce all the legal effects as long as it is not voided in a court procedure (i.e. it is not null and void) ${ }^{11}$. This provides an opportunity for any potential heirs to evaluate if they shall exercise their right and invalidate the will or, in case they believe will indeed represents testator's true intent, they shall leave the will to produce its legal effects ${ }^{12}$.

Unsurprisingly, Inheritance Act regulates types of will which can be found in other jurisdictions as well: there are two types of private written wills (holographic and allographic will), two types of public written wills (public will stricto sensu and international will) and one type of oral will ${ }^{13}$. Wills can be divided in different categories, but within the context of this paper, the most significant distinction of wills is whether they are formed in regular or extraordinary circumstances.

\subsubsection{Wills in regular circumstances}

In regular circumstances, testators can only draft a will in a written form. The simplest way to draft a will is to make a handwritten (holographic) will ${ }^{14}$. The only requirement for the validity of such will is that the will was written by the hand of the testator and signed. Therefore, a will written on a computer, printed and then signed would not be valid as a handwritten will. The signature on the will must leave no doubt as to who is the author of the will - therefore, it is recommended that a full name and surname are included in it - however, this is not strictly observed ${ }^{15}$.

Another type of private written will prescribed by the Inheritance Act is an allographic will (or written will in the presence of the witnesses) ${ }^{16}$. This will is valid, regardless of how its content was written down (i.e. if it was printed, handwritten by the testator, or someone else), as long as the testator declared that a document

\footnotetext{
11 Art. 29, par. 3. of the Inheritance Act.

12 This rule, actually, resembles the US harmless error doctrine - see infra, note 57.

13 Gavella; Belaj, op. cit., note 3, pp. 135 - 137. See also Šarčević, P.; Josipović, T.; Gliha, I.; Hlača, N.; Kunda, I., Family and Succession Law in Croatia in: Pintens, W. (ed.): International Encyclopaedia of Laws, Family and Succession Law, supplement 55, Wolters Kluwer, The Hague, 2011., p. 232.

14 Art. 30 of the Inheritance Act.

15 Gavella; Belaj, op. cit., note 3, p. 145.

16 Art. 31 of the Inheritance Act.
} 
contains his or her will in front of two simultaneously present witnesses and then signed the document.

Public will is a will expressed before an authorized person (public notary, municipal judge, or judge trainee and a consular/diplomatic-consular officer ${ }^{17}$. Testator's last will is expressed in a strict procedure intended to determine the true identity of the testator, his or her last wishes (which should be followed closely but formulated in accordance with the Inheritance Act) and the testator's mental capacity. At the end of procedure, testator signs the will and the authorized person certifies the will ${ }^{18}$. A special procedure is prescribed for cases in which the testator is unable to read the will ${ }^{19}$ or in case the testator does not use the language of the procedure ${ }^{20}$, if the testator is mute, deaf or deaf and blind ${ }^{21}$.

The last type of will is an international will22. This type of will was implemented into the Croatian legal system with the acceptance of the Convention Providing a Uniform Law on the Form of an International Will ${ }^{23}$. In this case, the testator simply confirms before the authorized person ${ }^{24}$ and two simultaneously present witnesses that a document represents his or her last will and that the testator is familiar with its content $\mathrm{t}^{25}$. The testator should then proceed to sign the will or recognize the signature placed on the will as his or her own. Afterwards, the witnesses and the authorized person sign the will. The authorized person then indicates the date of the will and issues a prescribed form confirming that the testator expresses his or her last will in accordance with the proper procedure.

\subsubsection{Wills in extraordinary circumstances}

As it is often the case comparatively, Inheritance Act foresees the validity of oral wills as well, but only if such wills were expressed in extraordinary circumstances when the testator is prevented from expressing the last will in any other valid

\footnotetext{
$17 \quad$ Art. $32-36$ of the Inheritance Act.

18 Gavella; Belaj, op. cit., note 3, p. 139, 140.

19 Art. 33 of the Inheritance Act.

20 Primarily, the Croatian language, but also one of the minority languages, when its equal use before pulic authorities is guaranteed by a special law.

21 Art. 150 of the Inheritance Act.

22 Art. 151 - 166 of the Inheritance Act.

23 Signed at Washington, 26. October 1971; Implemented by Official Gazette IA, No. 3/95.

24 These are a public notary, municipal judge, or judge trainee in Croatia and a consular/diplomatic-consular officer.

25 It is necessary to emphasize here that there are no language limitations in drafting of the international will - as the authorized person is not required in any way to review the content of the will. See, Art. 154/2 of the Inheritance Act - also see: Šarčević; Josipović; Gliha et al., op. cit., note 13, p. 241.
} 
form ${ }^{26}$. Such circumstances must be extraordinary - if the circumstances are lasting or permanent, oral will shall not be valid. Furthermore, it is considered that such circumstances exist only in case the testator's life is directly endangered ${ }^{27}$.

Testator's last will expressed orally must be witnessed by two simultaneously present witnesses who have a duty to write the content of the last will down and immediately deliver the document to the court or public notary for safekeeping. The fact that the witnesses have not fulfilled their duty, however, does not lead to invalidity of the last will.

If other conditions were met, orally expressed last will remains valid for a period of 30 days after the cessation of the extraordinary circumstances - meaning, if the testator survives the extraordinary circumstances, the legislator estimated that 30 days would be sufficient for expression of the last will in an another valid form.

\subsection{Efforts to harmonize inheritance law on the EU level}

Only certain aspects of the inheritance law are harmonized on the EU level. The crucial impediment to the development of the inheritance legal framework related on the European Union level is the lack of competence of the EU to carry out the complete harmonization of inheritance laws ${ }^{28,29}$. Even though parts of private law are harmonized on the EU level - it seems that harmonization bypassed the inheritance law, as other problems in divergences of national private law systems required more immediate attention ${ }^{30}$. However, after it was proclaimed in a number of instruments adopted at the EU level that in order to facilitate mutual recognition of decisions of Member States, it is necessary to harmonise conflict-of-laws rules and provide for the drawing-up of an instrument relating to wills and succession ${ }^{31}$, the

26 Art. 37 - 40 of the Inheritance Act.

27 German jurisprudence equalizes this with the threat of loss of testator capability. See Krätzschel, $o p$. cit., note 6, p. 269.

28 Private law on the EU level is harmonized primarily within the context of establishing and maintaining a functional internal market - see Josipović, T., Privatno pravo Europske unije - Opći dio, Narodne novine, Zagreb, 2020, p. 20.

29 Załucki, M., Attempts to Harmonize the Inheritance Law in Europe: Past, Present, and Future, Iowa Law Review, Vol. 103, No. 5, 2018, p. 2324.

30 Such as the consumer protection law - see $i b i d$. The area of the EU inheritance law was even described as "virgin territory" by Prof. Reinhard Zimmermann, the Director of the Max Planck Institute, emphasizing how this area of law is neglected - see ibid.

31 See Preamble p. 1 - 8 of the Regulation (EU) No 650/2012 of the European Parliament and of the Council of 4 July 2012 on jurisdiction, applicable law, recognition and enforcement of decisions and acceptance and enforcement of authentic instruments in matters of succession and on the creation of a European Certificate of Succession (OJ L 201, 27.7.2012, p.107); See also: Lechner, T., Die Reichweite des Erbstatuts in Abgrenzung zum Sachenrechtsstatut anhand der Europäischen Erbrechtsverordnung 
first significant harmonization of the inheritance law on the EU level took place. The result of this process is the Regulation 650/2012 $2^{32}$.

The Regulation 650/2012, however, deals primarily with the mutual recognition on decisions dealing with the succession, conflict of law rules and establishes the European certificate of succession and does not purport to harmonize material inheritance law on the EU level. Therefore, this represents the first and an important step in the harmonization of inheritance law and further steps are sure to follow.

\subsubsection{Further developments - laying foundations for the EU digital will?}

In 2014, the Estonian Ministry of Justice in close cooperation with the Estonian Centre of Registers and Information Systems and several project partners launched a project "Further developments in the area of interconnection of registers of wills" (hereinafter: "ICRW") aimed at exploring and enhancing the possibilities for exchanging succession related information and documents electronically between the Member States ${ }^{33}$. The project was co-funded by the European Commission based on the Multiannual European e-Justice Action Plan 2014-2018, which stipulates that an informal expert group on the interconnection of registers of wills should be created in co-operation with the Member States and notaries ${ }^{34}$.

One of the main goals of the ICRW was to draw attention of the Member States to the importance of using modern electronic solutions for registration of wills and for exchanging information related to succession matters. In order to do that, it is recommended that Member States should adopt all necessary legislations to form a platform for a cross-border exchange of information and data on succession and wills. Also, it is recommended that a real-time Internet-based search from the national respective registers should be created and made available to the legal professionals or citizens dealing with succession cases $^{35}$. In order to ensure this, the

650/2012, Band 19 in: Dörner, H.; Hess, B.; Mansel, H.P. (eds): Internationales und europäisches Privat- und Verfahrensrecht, Nomos, Baden-Baden, 2017, p. 23.

32 Op. cit., note 31. This was followed by the Commission Implementing Regulation (EU) No 1329/2014 of 9 December 2014 establishing the Forms referred to in Regulation (EU) No 650/2012 of the European Parliament and of the Council on jurisdiction, applicable law, recognition and enforcement of decisions and acceptance and enforcement of authentic instruments in matters of succession and on the creation of a European Certificate of Succession (OJ L 359, 16.12.2014, p. 30).

33 e-Justice Expert Group, Interconnection of Registers of Wills, Final Report, p. 1., available at: [https:// e-justice.europa.eu/fileDownload.do?id=a40a5542-6765-4ad0-9f42-5b1dcf70acd5], Accessed: 14 April 2021.

$34 \quad$ Ibid., p. 1.

35 IC RW Expert Group, Recommendations on Electronic Will Registration and Data Exchange, p. 6 - 7, available at: [https://e-justice.europa.eu/fileDownload.do?id=6198a645-a2c5-4c39-b712- 
exchange should encompass a) forwarding information on the existence of wills by using electronic means; b) forwarding a certified digitised copy of the will by using electronic means; and c) forwarding a copy of the succession certificate by using electronic means $s^{36}$.

In the context of cross-border succession, it is especially interesting to analyse the recommendation concerning the creation and forwarding of the digitised copy of the will. Regardless of its form and particular national legislations regulating the will, this would seem as a possible approach to create a unique European digital will. Member States' authorities tasked with conversion of the will into its digital form intended for cross-border use could check the basic requirements related to its formal validity pursuant to their own laws. Once the will is uploaded, in order to ensure smooth use of European digital will, a presumption of validity regarding its original form should be foreseen on the EU level. This could be one possible approach in digitisation and modernization of the part of inheritance law dealing with wills.

Currently, there is no central EU register tasked with the cross-border exchange of information on wills. However, the non-profit European Network of Registers of Wills Association ${ }^{37}$ has developed a platform, which interconnects 16 national registers of wills and enables to enquire information about the existence of wills ${ }^{38}$.

\section{INFLUENCE OF MEASURES AIMED AT CURBING GLOBAL PANDEMIC}

Governments around the world approached the problem of global pandemic in variety of ways - from general aloofness and complete passivity, to strict limitation of movement and socialization aimed at preventing further spread of disease. To make matters worse, with the passage of time these approaches changed - stricter measures were relaxed over the time, whereas dire statistics forced some to act more determined, creating a sort of legal insecurity, which is reflected on reduction of cross-border movement ${ }^{39}$. In the end, there is no common approach, but it can be observed that as another statistical wave of new COVID-19 cases approaches,

f24f93116935], Accessed: 14. April 2021.

36 Ibid., p. 7.

37 Croatian Notaries Chamber is currently only an observer member - for more information see: European Network of Registers of Wills Association - Members list, available at: [http://www.arert.eu/ Members.html?lang=en] Accessed 12.2February 2021.

38 ICRW Recommendations, op. cit., note 35, p. 2.

39 For an overview of introduced measures see European Centre for Disease Prevention and Control, Data on country response measures to COVID-19, available at: [https://www.ecdc.europa.eu/en/publications-data/download-data-response-measures-covid-19], Accessed 26. February 2021. 
similar measures are introduced ${ }^{40}$. Such measures can be broadly grouped and analysed in the context of their impact on the expression of wills.

\subsection{Restriction of movement and curfews}

One of the most common measures is the restriction of movement - whether there is a form of curfew during certain times, or a complete lock-down of an entire region, county or town - they severely affect the interaction of individuals. Croatian government introduced the restriction of movement on two occasions so $\mathrm{far}^{41}$. One the most discussed issue in relation to this measure, in the context of inheritance law is the unavailability of public authorities tasked with the formation of formal wills ${ }^{42}$.

As defined supra, if the testator chooses to draft his or her final will in a form of public will (which is definitely a preferred form if one expects that someone may try to invalidate the will after the testators passing), he or she must be able to visit the public notary or a judge. This might be aggravated if the movement is restricted ${ }^{43}$ or if the persons authorized to draft or witness the formal will in the isolated county are unavailable (due to illness or self-isolation).

In such cases, testators who can only express their last will in a form of a public will (e.g. a blind person) are especially endangered ${ }^{44}$. If such situation really occurred and the testators could not reach the authorized persons, they could only express their last will orally - and such a will should be regarded as valid, as they could not express their will in any other form.

However, having in mind that there is a significant number of public notaries (and, to a measure, court officials) in each county ${ }^{45}$ this does not seem as a likely

40 See Krätzschel, op. cit., note 6; Toader, I. A.; Dobrila, M. C., Testamentul privilegiat în contextul pandemiei determinate de coronavirusul SARS-COV-2 (COVID-19), Revista Universul Juridic, Vol. 2020, No. 3, 2020, pp. 39 - 53.

41 Odluka o zabrani napuštanja mjesta prebivališta i stalnog boravka u Republici Hrvatskoj Official Gazette No. 35/20, which prohibited citizens to leave their place of residence (which measure was soon relaxed to include a wider area in which citizens could freely move) introduced on 23. March 2020 and Odluka o zabrani napuštanja županije prema mjestu prebivališta ili boravišta u Republici Hrvatskoj Official Gazette No. 141/20, which prohibited citizens to leave the county in which their place of residence is situated, introduced on 23. December 2020.

42 Krätzschel, op. cit., note 6, p. 269.

43 Due to illness or preventive isolation. Cf. Krätzschel, op. cit., note 6, p. 269, 270.

44 Other testators could just express their last will in any other form of private will permitted by the Inheritance Act.

45 There are currently 328 notarial offices active in Croatia, pursuant to public notary register (available at: [https://www.hjk.hr/Uredi], Accessed 14 April 2021. Cf. Panz, A., Die Auswirkungen von SARS- 
scenario. Furthermore, even if such a situation occurred, it is likely that any person would be granted a pass to travel to a different county in order to arrange his or her legal affairs. Even Public Notaries Act ${ }^{46}$ permits public notaries to perform their duties outside of their official seat in case this is justified by an especially justified interest of their clients ${ }^{47}$.

\subsection{Isolation of individuals}

Another potential difficulty that comes into mind is a situation in which a testator is isolated - this could be because he or she is experiencing symptoms of the illness or if the testator was just exposed to the illness, whether at home, nursing home ${ }^{48}$, or hospital. In this case, there might be certain difficulties in forming the last will.

Primarily, the testator cannot reach any authorized person in this case, so public will is out of the question. This could be quite problematic in cases when the testator is hospitalized for a longer period or if he or she is isolated in nursing home as a preventive measure of protection. It is inconceivable in such circumstances that the public notary would have to dress protective gear in order to perform the duties required of him or her as a part of this process. On the other hand, the formalities of public will ensure that the testator was in full mental capacity during the expression of last will and that the testator was not under undue influence. By removing the possibility for a successful creation of public will (especially among the elderly population), there may be a surge of potential court proceedings aimed at invalidation of various private wills created during periods of isolation of these individuals. If a person is isolated at home for a longer period and has no contacts with the outside world, it would be very difficult to ascertain whether the testator had a mental capacity to execute such legal act (as witnesses' testimonies are important for ascertaining the existence of adequate capacity $\left.{ }^{49}\right)$.

Furthermore, another problem is that in some cases of isolation, the testator would have trouble finding suitable witnesses ${ }^{50}$. This reduces testator's options

CoV-2 auf die notarielle Tätigkeit, Zeitschrift für das Notariat in Baden-Württemberg, Heft 1, p. 8.

46 Official Gazette No. 78/93, 29/94, 162/98, 16/07, 75/09, 120/16.

47 Art. 29, 30 of the Public Notaries Act.

48 Cf. Schaltke, M., Corona-Fälle aus der Rechtsschutzpraxis, Neue Juristische Wochenschrift, Heft 38, 2020, p. 2759.

49 This is regularly followed by an expertise of a medical expert witness - see e.g. Supreme court decisions number Rev-2691/90, Rev-1439/94, Rev-1098/06 and County court in Varaždin decision no. Gž$1 / 20$.

50 Having in mind that the most common available witnesses would be persons living with the testator in most of the cases, these are testator's family members. However, a defined circle of testator's family cannot be regarded as proper witnesses as they are expressly disqualified as witnesses in Art. 35 of the 
just to a holographic will ${ }^{51}$. In this case, the testator must be able to write and must have proper material to write the will on at his or her disposal. Naturally, in most cases that would be paper, regularly available at any household, but even if testator would run out of paper for any reason, it should be noted that the Inheritance Act does not require that the will is written on the paper - it could be any other material suitable for writing (e.g. piece of cardboard, packaging, wood, wall, etc. $)^{52}$. Certainly, a more significant problem seems to be testator's ability to write. If he or she is in such a state that his or her handwriting is illegible, the will would certainly be invalid (as his or her last will would be undeterminable).

Finally, problems of finding suitable witnesses could prevent the testator to successfully express a valid oral will.

\subsection{Difficulties in drafting public wills}

It seems that most of restrictions, whether in form of curfews, lock-downs or isolation of individuals, seriously affect the possibility of drafting public wills. Public notary can also perform his or her duties outside of the office ${ }^{53}$, but this is not of much use if the contact with the isolated person is forbidden entirely ${ }^{54}$. This is already described supra under 3.1 and 3.2.

Further difficulties in drafting public wills may be caused by the limited availability of the authorized persons due to rules restricting their working hours or possibilities of overt contact with the potential testators ${ }^{55}$.

Regulations in force prescribe that the formal will shall be expressed in the presence of an authorized person. If such contact is impossible, there is no possibility for drafting a valid formal will. Currently, there are no provisions enabling public notaries to use the electronic communication systems in performing their official

Inheritance Act. Furthermore, even if persons living with the testator are not mentioned in the Art. 35, if they are witnessing testator's last will, they cannot receive any benefit in any form therefrom (Art. 36).

51 Cf, similarly - Toader; Dobrila, op. cit., note 40, p. 51.

52 Gavella; Belaj, op. cit., note 3, p. 145. In comparative analysis, there are numerous examples of wills being written on strange, even bizarre materials - one of the most famous US cases involves a will scratched on a tractor fender, made by an unfortunate testator after he was crushed by his tractor in an accident. In probate proceedings, tractor fender was brought into the courthouse and it was deemed that the testator made a valid handwritten will. See Horton D.; Kress Weisbord, R., COVID-19 and Formal Wills, Stanford Law Review Online, 73, p. 23.

53 Article 20 of the Public Notary Rules of Procedure Official Gazette No. 120/14.

54 Cfsimilarly Toader; Dobrila, op. cit., note 40, str. 48.

55 For example, Croatian courts only held urgent hearings - see European Commission, Comparative Table on COVID-19 Impact on Civil Proceedings, available at: [https://e-justice.europa.eu/fileDownload. do?id=f74aa89f-e4c7-4946-8e6e-985b6b250473], Accessed 15 March 2021. 
duties. However, recently Croatian Notaries Chamber published a call for the delivery of offers to design and maintain a platform for teleworking ${ }^{56}$. Judging by the content of this call, there is an initiative to provide a possibility for public notaries to offer their services by using means of electronic communication. This is a welcome step, which would render most of mentioned issues obsolete. After such platform is active, it will surely be followed by necessary regulatory changes.

Again, it is necessary to emphasize that despite these potential obstacles, testators could draft a last will in any other valid form. If drafting of the regular will is impossible, they can make an oral testament in accordance with the rules on the extraordinary will.

\section{THE USE OF ELECTRONIC TOOLS IN TESTAMENTARY DISPOSITIONS}

Within the context of the problems related to application of provisions of Inheritance Act described supra, the next step is to analyse whether such problems can be alleviated or entirely solved through use of various electronic tools. Two approaches come into mind here - current legal framework could be adapted by a more loose interpretation of norms, or the legal framework can be entirely changed to accommodate new legal instruments.

In this context, it must be noted that the Croatian inheritance law (like in other civil law systems) is subject to strict interpretation rules and the mentioned loose interpretation does not encompass approaches such as harmless error doctrine ${ }^{57}$ in which certain deficiencies in the procedure can be overlooked for the overall protection of the testator's true intent.

\subsection{Adaptation of current legal solutions}

\subsubsection{Recording - a mixed will or a facilitation tool?}

Testator, especially one who is isolated from social contacts, may decide to record his or her last will. Most of us today carry some sort of portable device that has the option of recording of video, or at least, the voice. This may lead some to decide and to record their last will.

\footnotetext{
56 Published on web page of Croatian Notaries Chamber, available at: [https://www.hjk.hr/], Accessed 26 February 2021.

57 Developed in Australian jurisprudence in the 1970s and widely used in the US - it allows judges to enforce a writing which does not comply with the US Wills Act if there is clear and convincing evidence that the testator intended it to be effective - Horton; Weisbord, op. cit., note 52, p. 24.
} 
In comparative jurisprudence, in common law jurisdictions, the question of acceptability of a recorded last will was in some cases posed before the courts deciding on validity of such wills ${ }^{58}$. Australian jurisprudence seems to be most inclined to accept such wills - for example in a case before the Queensland Supreme Court a video recording on a mobile phone belonging to Marion Demowbray was declared a valid final will ${ }^{59}$. In another example before the Supreme Court of the State of Victoria, a will recorded with the web camera was considered valid ${ }^{60}$.

Pursuant to the Inheritance Act, a visual or a voice recording would not represent a valid will. However, it would represent a helpful tool to ascertain the correct content of the last will and the capacity of the testator. In a case before the Court of Appeal of Louisiana Corley v. Munro ${ }^{61}$, an elderly testator who made nine wills previously, wanted to make sure that the last one will be valid. In order to achieve that she recorded the whole testamentary procedure even inviting the doctors to establish that she has the necessary mental capacity. As she expected, after her passing, her last will was challenged as invalid, due to lack of mental capacity, but the court rejected the motion on the basis of the videotape, which was further analysed by psychiatric experts in the court proceedings ${ }^{62}$.

Furthermore, some interesting issues may arise here - suppose that the testator is making an oral will in extraordinary circumstances. The testator wishes that his or her last will is correctly and precisely relayed to his or her heirs so he or she decides to make a recording of the ceremony. After testator's passing, witnesses repeat testator's last will in front of the judge at municipal court. The judge then draws up an official record containing the content of the testator's last will and proclaims the official record as the testator's will in accordance with the law. However, whether intentionally or accidentally, they completely alter the content of the will. Upon hearing the testator's recording, potential heirs discover that this is in a complete contradiction to the proclaimed will. In the potential clash of the evidentiary value of a recording and a testimony, it is quite likely that the court, absent other evidence, would decide that the recording as a more reliable

58 For a good overview of some more famous cases of use of various electronic devices in drafting wills in comparative jurisprudence - see Klasiček, $o p$. cit., note 4.

59 Ibid. p. 39.

${ }^{60}$ Estate of Sheron Jude Ladduhetti, unpublished judgement - see Załucki, M., op. cit., note 4, p. 8.

${ }_{61}$ Court of Appeal of Louisiana, Third Circuit. 2. February 1994. 631 So. 2d 708.

62 Perrillo Rodriguez, M., Testamento audiovisual: Una evolucion al derecho de sucesiones, Trust and Estates 53, no. 2, 2014, p. 293. Cf. decision of County court in Zagreb, No. Gž-5980/17 - audio recording of a testament was used as a template for allographic will which was later written down. 
evidence $^{63}$ (provided that, of course, the recording is not a forgery itself). In this case, heirs can try to invalidate the proclaimed will, as a forgery. However, how can they validate the true will of the testator? Can they initiate the court procedure to prove the existence of a destroyed, lost and hidden will (a procedure foreseen primarily for written wills)? ${ }^{64}$ A loose interpretation of Art. 50 may offer a solution - it stipulates that the provisions of will must be interpreted according to the true intent of the testator. Would the court be permitted to disregard the official content of the will to follow the true intent of the testator even if these two are in obvious contradiction? ${ }^{65}$

Due to clear wording of the Art. 37, the recording, regardless of its reliability or quality, cannot replace the witness and it cannot be inferred that a witness was present if he or she later saw or heard the recording - the Inheritance Act clearly stipulates that two witnesses must simultaneously be present before the testator at the moment of his or her oral expression of the last will. So the validity of any kind of mixed will would be out of the question.

In the end, it can be concluded that within the current framework a recording (whether audio-visual or vocal) can only be used as a tool that facilitates the determination of testator's true intent and his or her mental capacity ${ }^{66}$.

\subsubsection{Digital holographic wills}

Holographic wills are one the simplest wills that can be made by a potential testator. One only needs a piece of paper and a pen to write a will. However, in the digital era, we often find ourselves lacking these items and the amount of written documents (including personal notes) is diminishing.

In 2012, a terminally ill patient in the US hospital refused a blood transfusion for religious reasons. He was aware that this would certainly lead to his death, so he called his brother to help him prepare the last will. His brother did not have any

63 See - evidentiary value in common law proceedings - for audio recordings: Beyer, G. W.; Hargrove, C. G., Digital Wills: Has the Time Come for Wills to Join the Digital Revolution, Ohio Northern University Law Review, Vol. 33, No. 3, p. 881; for video recordings - ibid., p. 884.

64 Art. 41 of the Inheritance Act.

65 It seems that this was not of concern for the legislators, having in mind that the regulation of this type of oral will remained relatively unchanged since 1955 - although the issues related to the audio recorded wills in extraordinary circumstances appeared much earlier in the $20^{\text {th }}$ century than one would expect - in Nazi Germany, courts refused to recognize the validity of a will recorded on a gramophone - see Załucki, op. cit., note 4, p. 3.

66 Additional actions undertaken in the testamentary process, even if they are not foreseen by the law as necessary, do not cause will's invalidity (unless they are explicitly forbidden) - see decision of the County court in Varaždin, No. Gž-230/09. 
paper or pencil with him, so he took his touchscreen tablet. Testator's last will was ultimately written down and signed using stylus for tablets. After his passing, the Ohio probate court confirmed that such will satisfied all the conditions for written will ${ }^{67}$.

Croatian courts could as well be faced with a question whether a will written down by using electronic device that transmits or recreates testator's handwriting, may be accepted as a valid holographic.

Pursuant to Art. 30 of the Inheritance Act, there are only two conditions for the validity of the holographic will - it must be personally handwritten and signed by the testator. It is deemed that a will typed down with the help of a device (such as a computer or a typewriter) does not constitute a valid holographic will ${ }^{68}$. The main reason for this is to avoid the counterfeiting of the will - handwritten will can easily be compared with a specimen of handwriting of a testator to ascertain whether this indeed represents his or her handwriting ${ }^{69}$. However, if a device realistically and precisely captures one's writing - could this be considered as handwriting for the purpose of holographic will? There are opposing views on this matter in the European legal doctrine ${ }^{70}$. It is necessary to emphasize that in drafting the holographic will, the material, which captures the handwriting itself, is irrelevant ${ }^{71}$. Therefore, if an electronic device captures the handwriting to a sufficient detail that allows its comparison, there seem to be no obstacles to recognizing such will as a valid holographic will. ${ }^{72}$

67 Estate of Javier Castro, No. 2013ES00140 (Ohio C.P., 19. June 2013) - See Banta, N., Electronic Wills and Digital Assets: Reassessing Formality in the Digital Age, Baylor Law Review, Vol. 71, No. 3, p. 580, 581.

68 See Gavella; Belaj, op. cit., note 3, p. 134; Kreč, M.; Pavić, Đ., Komentar Zakona o nasljedivanju sa sudskom praksom, Narodne Novine, Zagreb, 1964., p. 202.

${ }_{69}$ Cf. Beyer; Hargrove, op. cit., note 63, p. 877 - 891; Developments in the Law: More Data, More Problems, Harvard Law Review, No. 6, 2018, p. 1793. This argument, however, is also becoming obsolete, as more and more people are using electronic devices to make notes and draft documents, so in some cases, there aren't any specimens of testator's handwriting that could be compared to the holographic will - see Beyer; Hargrove, op. cit., note 63, p. 898, Sasso, op. cit., note 3, p. 188.

70 See Sasso, op. cit., note 3, p. 187 - Sasso claims that writing on a touch screen does not materially imprint the author's writing on a surface, but merely sends the computer's memory input to reproduce handwriting on the screen through conversion into a binary sequence that by its nature is duplicable and modifiable. For a different view which seems to support the treatment of such input as handwriting, under the condition that the graphic reproduction of handwriting is not distorted - see Hren, P., Oblik oporok v slovenskem pravu in možnost elektronske oporoke, Pravni letopis, 2017, p. 198, 201.

71 See Kreč; Pavić, op. cit., note 68, p. 202. Cf. Krätzschel, op. cit., note 6, p. 269.

72 Another frequently discussed issue closely related to this question is whether a will with electronic signature could be deemed valid, as the electronic signature substitutes subject's signature in legal acts. This would have to be answered in negative, as holographic will must entirely be handwritten. 


\subsection{New potential solutions}

To overcome the potential issues described supra under point 3, it is also possible to introduce a completely new set of measures (as opposed to more loose interpretation of the current legal framework analysed supra). Legislators comparatively already introduced a number of different measures. Some comparative legal solutions existed from long before coronavirus appeared and could prove valuable in the current circumstances. In addition, because some of these solutions are in place for a certain period, it is already possible to see if such solutions are working and what problems arise in association with them.

\subsubsection{Remote witnessing}

One of the best solutions to overcome the problems in finding suitable witnesses is the introduction of remote witnessing. The United Kingdom amended its Wills Act of 1837 so that the presence of those making and witnessing wills includes a virtual presence, via video-link, as an alternative to physical presence ${ }^{73}$. This amendment is temporary, however, and will only encompass wills made between 31 January 2020 until 31 January 2022. UK government published a detailed guidance for those who wanted to use the new solution; however, it is still emphasized that traditional forms of wills should be preferred ${ }^{74}$. The type of video-conferencing or device used in remote witnessing is not important, as long as the person making the will and their two witnesses each have a clear line of sight of the writing of the signature. Similar measures have been introduced in certain US states ${ }^{75}$.

Pursuant to the Inheritance Act, the allographic will can be drafted in front of two simultaneously present witnesses. The term presence has not yet been interpreted by the Croatian courts in order to encompass virtual presence as well. However, in other areas of civil law this question has been raised and even resolved - Art. 293 of the Obligations $\mathrm{Act}^{76}$ which regulates the conclusion of contracts in electronic form deems an offer given in an electronic form as an offer to a present person if that person can immediately respond with a counter-statement to any statement of the offeror. If such a regime is foreseen for conclusion of contracts, could it be extended to drafting of wills as well? This seems unlikely, given that the basic prin-

73 See - UK Government, Guidance on making wills using video-conferencing, available at: [https://www. gov.uk/guidance/guidance-on-making-wills-using-video-conferencing], Aaccessed 09 March 2021.

74 Ibid. See also - the BBC, Coronavirus: Wills witnessed by video link to be made legal, available at: [https://www.bbc.com/news/uk-53530228], Accessed 09 March 2021.

75 Connecticut, Illinois, Kansas, Michigan, New York, Tennessee and Washington DC - See Horton; Weisbord, op. cit., note 52, p. 27.

76 Official Gazette No. 35/05, 41/08, 125/11, 78/15, 29/18 
ciple of obligation law is the informality of contracts, whereas the will is a strictly formal legal act, so no loose interpretation could be applied to the procedure of drafting a will - this option would have to be explicitly foreseen in the law.

Apart from clear advantages of having such an option in the process of drafting of a will, one must not forget the possible disadvantages. Remote witnessing increases the possibility of fraud - with increasingly developing technologies (such as deepfake for example), it seems increasingly easy to recreate a fake witness or to provide fake statement by a person involved in a procedure. Furthermore, the interaction of the witnesses with the testator is limited to the duration of live feed. This could be important if the question of testator's mental capacity arises - if the witnesses are physically present with the testator, they can observe his or her behavior immediately before and after the expression of last will and will likely engage with him or her in a conversation or small talk - this can either convince them that the testator is mentally fit or unfit to draft a last will. In case of remote witnessing, this important social aspect is left out ${ }^{77}$.

\subsubsection{Digital will}

Different meanings are attached to the term digital will - it can either mean i) a set of issues related to the post mortem transfer of one's digital assets, or ii) a last will drafted with the help of electronic devices and saved in the digital form ${ }^{78}$. The term digital will in the latter meaning is often interchangeably used with the term electronic will and it is used to denote a number of various forms of wills created with the help of digital technologies - from wills made in the form of video recording to the ones made in a form of an electronic document or a note ${ }^{79}$. Regardless of the method of its capture into the digital format, the digital wills could be separated into three different categories on the basis of their security and formalities that have to be completed in their drafting ${ }^{80}:$ i) offline digital wills are simple typed and/or recorded wills stored onto an electronic device; ii) online digital wills are wills that are uploaded on a server belonging to a private actor (posted on social media, stored in the cloud, sent in form of an e-mail message, etc.) - they exist on the internet and are a subject to data protection laws; and finally there are iii) qualified custodian wills where a subject, acting as a qualified custodian (whether

\footnotetext{
77 Cf. Ghatak C., Leaving My Legacy Online - Weighing the Viability of Recognising Digital Wills in India, Nirma University Journal, Vol. 7, No. 1., 2018, p. 96.

78 Sasso, op. cit., note 3, p. 171.

79 Cf. Hren, op. cit., note 70, p. 197, 198.

80 More Data, More Problems, op. cit. note 69, p. 1791, 1792.
} 
a private company or a public institution or organisation) creates and stores the testator's will ${ }^{81}$.

Although courts in some common law jurisdictions have decided on the validity of certain offline and online digital wills ${ }^{82}$ and although there are already private companies offering services of creating and storing digital wills thus acting as custodians (although such companies always have the option of printing the will which is then sent to the testator so he or she can sign it in a proper procedure to satisfy legal conditions for its validity) only few jurisdictions have actually regulated the digital will and set conditions for its validity. Nevada Electronic Wills Statute from $2001^{83}$ is certainly the most interesting for the analysis. It prescribes that the will can be drafted in an electronic form (not specifying the type of electronic record the will must be stored on) and it must contain testator's signature (in addition, the will must include at least one of authentication characteristics of the testator - this can be the digitized signature of the testator, retinal scan, fingerprint, etc.). Furthermore, there can only be one authoritative copy of testator's will which is original, unique, identifiable and unalterable and which is controlled by the testator or a custodian designated by the testator. Any and all attempts at its alteration must be identifiable and all copies must be readily identifiable as copies ${ }^{84}$.

From these requirements it is immediately clear what was the main concern of the experts working on the statute - as the computer are the perfect copying machine, every copy is a perfect copy, indistinguishable from the original it is very hard to determine which file containing the will is the original unaltered file ${ }^{85}$. Any tampering with the will by a third party after the death of the testator must therefore be easy

$81 \quad$ Ibid., p. 1791, 1792.

82 Digital will in form of a note in Evernote application deemed valid under harmless error doctrine (State of Michigan) - see case Estate of Horton - In re Estate of Horton, Harvard Law Review, Vol. 132, No. 7, 2019, pp. 2082 - 2089; digital will in form of a word document deemed valid (State of New South Wales) - see case Yazbek v Yazbek - Klasiček, op. cit. note 4, p. 34, 35; digital will in form of a document stored on iPhone deemed valid (State of Queensland) - see case Re: Yu - Klasiček, op. cit. note 4, p. 37, 38; digital will in a document saved on a hard disc, accompanied by a handwritten statement that the electronic document represents last will of the deceased deemed valid (South Africa) - see case MacDonald v. The Master - Snail, S.; Hall, N., Electronic Wills in South Africa, Digital Evidence and Electronic Signature Law Review, Vol. 7, 2010, pp. 67 - 70; digital will signed by the testator by typing his name in a cursive font and then subsequently signed by witnesses deemed valid (State of Tennessee) - see case Taylor v. Holt - Boddery, S., Electronic Wills: Drawing a Line in the Sand against Their Validity, Real Property, Trust and Estate Law Journal, Vol. 47, No. 1, 2012, p. 202 - 203; a digital will in form of an unsent text message stored on a mobile phone deemed valid (State of Queensland) - see case Nichol v. Nichol-More data, more problems, p. 1806.

$83 \quad$ Nev. Rev. Stat. $\$ 133.085$.

84 Beyer; Hargrove, op. cit., note 63, p. $887-889$.

85 Ibid, p. 891. Sasso, op. cit., note 3, p. 174. 
to detect. Even during testator's life, in case someone hacks testator's will and alters it, the testator could be oblivious to this for a long period of time - this is not a problem with the traditional forms of will in which copies and alterations to the original will are easier to identify and wills in material form can be kept by the testator in a safe or a similar place easily accessible to him or her ${ }^{86}$.

Technology that could satisfy all of the above-mentioned criteria was not readily available to the general population; therefore, the legislation was virtually inapplicable at first after its introduction ${ }^{87}$. Only in 2009 did the State of Nevada establish a legal framework for establishing and maintaining the Nevada Lockbox - an online registry that allows a person to post an electronic copy of a will (...) and retrieve that document when needed ${ }^{88}$. Having to choose between making a complex legal act involving the use of biometric data retriever as well as entering in a relationship with a qualified custodian on one hand and making a simple handwritten will on the other hand clearly hinders the further development of the digital will in Nevada. Finally, although paper is a material also prone to degradation with the passing of time, media carrying electronic data are far less reliable ${ }^{89}$. Only cloud storage offers a relatively secure option for a long-term storage if servers are regularly maintained and replaced. However, due to extremely speedy advancement of technology, it is questionable whether the software in the future would support reading of files created 20,30 or 40 years before, as even in the shorter time spans serious problems arise in reading files made with an out-dated versions of software. Despite of these difficulties, a number of US States have adopted statutes permitting some sort of digital will since ${ }^{90}$ and some authors are even supporting their introduction in certain European states ${ }^{91}$.

In conclusion, despite the widespread use of digital technologies and electronic devices, the introduction of a purely digital will would trigger more problems than benefits (as it is evident from the comparative perspective) and citizens who are able to form their testamentary disposition in digital form would rather opt for a traditional form of will. Therefore, it seems that the digital will shall reach affirmation in the future once the technological solutions exist that can eliminate the abovementioned problems. Having in mind the affirmation of technologies

\footnotetext{
86 Also, there must be a way to determine when was will created and/or altered - this one of the main issues with wills in currently valid forms as well - see e.g. decision of County court in Rijeka - No. Gž-516/19.

87 See Boddery, op. cit., note 82, p. $199-200$.

88 Ibid, p. 200.

89 See Beyer; Hargrove, op. cit., note 63, p. 894, 895.

90 For example Arizona, Florida and Indiana - see Horton; Weisbord, op. cit., note 52, p. 26.

91 See Sasso, op. cit., note 3, p. 191.
} 
involving the use of biometric data, spread of personal encryption and authentication software (such as tokens) and increasing number of safe deposit services and services intended for communication of citizens with the government (such as the e-gradanin in Croatia), this moment could be soon.

\subsubsection{Electronically certified will}

Finally, similarly to remote witnessing, there is a possibility of remote notary certification of the will - the entire testamentary process could be performed by the use of electronic devices, so that the testator and the public notary (or a court official) do not come into physical contact. This approach is often comparatively discussed $^{92}$ and, judging by some activities (see point 3.3 supra), it could soon appear in Croatia as well.

Current legal framework does not allow a notary to remotely certify a will and the provisions of the Inheritance Act foresee that the entire testamentary process in drafting of a public will happens in the presence of the public notary (or a court official). Therefore, the current legal framework would have to be adjusted for the introduction of remote notary certification of the will.

\section{CONCLUSION - DO WE NEED A NEW TYPE OF WILL?}

The use of electronic devices and digital technologies has entered almost every aspect of our everyday lives and the law is adapting to these circumstances. Inheritance law, as a more conservative branch of law, seems to resist these changes. An extraordinary set of circumstances, in the form of rapid spread of global pandemic, have intensified the discussion related to the introduction of new solutions that foresee the use of electronic devices and digital technologies in the process of testamentary disposition. The pandemics have not caused the total disruption of our everyday lives to such an extent that serious measures had to be introduced into civil law (and hence, there is still no urgent need to introduce such measures in inheritance law). However, some changes that would eventually occur have been expedited. One such change is a possible introduction of remote notary certification.

Another way to facilitate drafting of the will in the times of pandemics is to introduce remote witnessing option, however, such option would only be reserved for extraordinary circumstances due to its shortcomings ${ }^{93}$ (possibility of mimicking

\footnotetext{
92 See Sasso, op. cit., note 3, p. $181-184$

93 As pointed out supra, the UK also limited the validity of wills drafted with the use of remote witnessing to 2 year.
} 
someone's appearance which leads to uncertainties related to identification of individuals and a limited possibility of assessing someone's mental capacity to draft a legal act). Remote witnessing cannot replace the actual spatial presence of witnesses foreseen by the current Croatian legal framework.

Another important aspect of introduction of digital technologies in the inheritance law is the introduction of a digital will. This seems unlikely to happen soon in Croatia, as well as in other EU countries ${ }^{94}$, although tendencies to recognize the validity or regulate the digital will already appeared in certain common law jurisdictions. However, in the EU succession law, there is a tendency to establish a joint database for succession cases and wills. Initiative also calls for digitisation of existing wills drafted in accordance with the laws of Member states where the will was drafted. This could be a basis for the creation of an instrument such as the European digital will. Based on the data published by the European Commission ${ }^{95}$, there are approximately 450.000 cross-border succession cases in the EU. In this context, such tools could greatly improve the smooth functioning of the internal market and cross-border succession procedure.

Digital holographic wills are the only types of digital will that currently could be recognized as valid in Croatia, although the question whether digitised handwriting satisfies the criteria for handwritten will is still comparatively heavily debated.

Some consider that a video recording of the last will could represent a valid alternative for a holographic will ${ }^{96}$, however, such will would not be recognized as a will due to strict wording of the Inheritance Act.

In conclusion, it could be foreseen that changes to the inheritance law, in the form of introduction of digital technologies, are inevitable and are probably expedited due to COVID-19. However, having in mind the stability of inheritance law institutes, the changes would certainly not be dramatic, but incremental. Let us not forget that it took written will centuries to become the regular form of will and to replace the oral will, which is today still widely recognized (at least in its form of extraordinary will) ${ }^{97}$.

\footnotetext{
94 An initiative to include typed or digital holographic will in German law was unsuccessful - see Sasso, op. cit., note 3, p. 178. There are also initiatives to modernize Polish, Swiss, Dutch and UK inheritance law - see Załucki, op. cit., note 4, p. 10.

95 ICRW Expert Group, Recommendations on Electronic Will Registration and Data Exchange, p. 1.

96 Sasso, op. cit., note 3, p. 189.

97 Cf. Beyer; Hargrove, op. cit., note 63, p. 896.
} 


\section{REFERENCES}

\section{BOOKS AND ARTICLES}

1. Banta, N., Electronic Wills and Digital Assets: Reassessing Formality in the Digital Age, Baylor Law Review, Vol. 71, No. 3, pp. 547 - 603

2. Beyer, G. W.; Hargrove, C. G., Digital Wills: Has the Time Come for Wills to Join the Digital Revolution, Ohio Northern University Law Review, Vol. 33, No. 3, pp. 865 - 902

3. Boddery, S., Electronic Wills: Drawing a Line in the Sand against Their Validity, Real Property, Trust and Estate Law Journal, Vol. 47, No. 1, 2012, pp. 197 - 212

4. Developments in the Law: More Data, More Problems, Harvard Law Review, No. 6, 2018, pp. $1714-1811$

5. Gavella, N.; Belaj, V., Nasljedno pravo, Narodne novine, Zagreb, 2008

6. Ghatak C., Leaving My Legacy Online - Weighing the Viability of Recognising Digital Wills in India, Nirma University Journal, Vol. 7, No. 1, 2018, pp. 87 - 98

7. Horton D.; Kress Weisbord, R., COVID-19 and Formal Wills, Stanford Law Reivew Online, 73 , pp. $18-27$

8. Hren, P., Oblik oporok v slovenskem pravu in možnost elektronske oporoke, Pravni letopis, 2017, pp. $187-202$

9. In re Estate of Horton, Harvard Law Review, Vol. 132, No. 7, 2019, pp. 2082 - 2089

10. Josipović, T., Privatno pravo Europske unije - Opći dio, Narodne novine, Zagreb, 2020

11. Josipović, T., Restrictions of Fundamental Rights in Private Law Relations in the Special Legal Order, with Exceptional Regard to the Specific Circumstances Caused by the Epidemic, Central European Journal of Comparative Law, Vol. 1., No. 2., 2020, pp. 59 - 86

12. Klasiček, D., $21^{\text {st }}$ century wills, Pravni Vjesnik, Vol. 35, No. 2, 2019, pp. $29-48$

13. Krätzschel, W., Die Errichtung letztwilliger Verfügungen in Corona-Zeiten, Zeitschrift für Erbrecht und Vermögensnachfolge, Heft 5, 2020, pp. 268 - 272

14. Kreč, M.; Pavić, Đ., Komentar Zakona o nasljeđivanju sa sudskom praksom, Narodne Novine, Zagreb, 1964

15. Lechner, T., Die Reichweite des Erbstatuts in Abgrenzung zum Sachenrechtsstatut anhand der Europäischen Erbrechtsverordnung 650/2012, Band 19 in: Dörner, H.; Hess, B.; Mansel, H.P. (eds): Internationales und europäisches Privat- und Verfahrensrecht, Nomos, Baden-Baden, 2017

16. Maganić, A., Gradanskopravno pravosude za vrijeme pandemije bolesti COVID-19, unpublished, Zagreb, 2021. - lecture held at Croatian Academy of Sciences and Arts, 22. January 2021

17. Panz, A., Die Auswirkungen von SARS-CoV-2 auf die notarielle Tätigkeit, Zeitschrift für das Notariat in Baden-Württemberg, Heft 1, pp. 2 - 10

18. Perrillo Rodriguez, M., Testamento audiovisual: Una evolucion al derecho de sucesiones, Trust and Estates 53, No. 2., 2014, pp. 285 - 306

19. Rabl, C.; Zöchling-Jud, B. (eds): Das neue Erbrecht, MANZ'sche Verlag, Wien, 2015 
20. Šarčević, P.; Josipović, T.; Gliha, I.; Hlača, N.; Kunda, I., Family and Succession Law in Croatia in: Pintens, W. (ed.): International Encyclopaedia of Laws, Family and Succession Law, supplement 55, Wolters Kluwer, The Hague, 2011

21. Sasso, I., Will formalities in the digital age: Some Comparative Remarks, Italian Law Journal, Vol. 4, No. 1, 2018, pp. 169 - 194

22. Schaltke, M., Corona-Fälle aus der Rechtsschutzpraxis, Neue Juristische Wochenschrift, Heft 38, 2020, pp. $2758-2761$

23. Snail, S.; Hall, N., Electronic Wills in South Africa, Digital Evidence and Electronic Signature Law Review, Vol. 7, 2010, pp. 67 - 70

24. Toader, I. A.; Dobrila, M. C., Testamentul privilegiat în contextul pandemiei determinate de coronavirusul SARS-COV-2 (COVID-19), Revista Universul Juridic, Vol. 2020, No. 3, 2020, pp. $39-53$

25. Załucki, M., About the Need to Adjust the Regulations regarding the Form of Will to the Modern Requirements, European Journal of Economics, Law and Politics, Vol. 6, No. 2, 2019, pp. $1-13$

26. Załucki, M., Attempts to Harmonize the Inheritance Law in Europe: Past, Present, and Future, Iowa Law Review, Vol. 103, No. 5, 2018, pp. 2317 - 2338

\section{EU LAW}

1. Commission Implementing Regulation (EU) No 1329/2014 of 9 December 2014 establishing the Forms referred to in Regulation (EU) No 650/2012 of the European Parliament and of the Council on jurisdiction, applicable law, recognition and enforcement of decisions and acceptance and enforcement of authentic instruments in matters of succession and on the creation of a European Certificate of Succession (OJ L 359, 16.12.2014, p. 30)

2. Regulation (EU) No 650/2012 of the European Parliament and of the Council of 4 July 2012 on jurisdiction, applicable law, recognition and enforcement of decisions and acceptance and enforcement of authentic instruments in matters of succession and on the creation of a European Certificate of Succession (OJ L 201, 27.7.2012, p.107)

\section{LIST OF NATIONAL REGULATIONS, ACTS AND COURT DECISIONS}

1. Inheritance Act - Official Gazette of the Federative People's Republic of Yugoslavia No. $20 / 55$

2. Nevada Electronic Wills Statute from 2001 (Nev. Rev. Stat. $\$ 133.085$ )

3. Odluka o zabrani napuštanja mjesta prebivališta i stalnog boravka u Republici Hrvatskoj Official Gazette No. 35/20, introduced on 23. March 2020

4. Odluka o zabrani napuštanja županije prema mjestu prebivališta ili boravišta u Republici Hrvatskoj Official Gazette No. 141/20, introduced on 23. December 2020

5. Public Notaries Act - Official Gazette No. 78/93, 29/94, 162/98, 16/07, 75/09, 120/16

6. Public Notary Rules of Procedure - Official Gazette No. 120/14

7. Convention Providing a Uniform Law on the Form of an International Will - Signed at Washington, 26. October 1971; Implemented by Official Gazette IA, No. 3/95 
8. Act on Amendment of Act on Enforcement over Monetary Assets - Official Gazette No. $47 / 20$

9. County court in Rijeka decision no. Gž-516/19

10. County court in Zagreb decision no. Gž-5980/17

11. Supreme court decision no. Rev-1439/94;

12. Supreme court decision no. Rev-2691/90

13. Supreme court of the South Africa - case MacDonald v. The Master

14. Supreme court of the State of New South Wales - case Yazbek v Yazbek

15. Supreme court of the State of Queensland - case Nichol v. Nichol

16. Supreme court of the State of Queensland - case Marion Demowbray

17. Supreme court of the State of Queensland - case Re: Yu

18. Supreme court of the State of Tennessee - case Taylor v. Holt

19. Supreme court of the State of Victoria, Estate of Sheron Jude Ladduhetti, unpublished judgement

20. County court in Varaždin decision no. Gž-230/09

21. Supreme court decision no. Rev-1098/06

22. Inheritance Act - Official Gazette No. 48/03, 163/03, 35/05, 127/13, 33/15, 14/19

23. Obligations Act - Official Gazette No. 35/05, 41/08, 125/11, 78/15, 29/18

24. Court of Appeal of Louisiana, Third Circuit. 2.2.1994. - 631 So. $2 \mathrm{~d} 708$ Corley v. Munro

25. Ohio C.P, 19.6.2013. - No. 2013ES00140 Estate of Javier Castro

26. Michigan court of Appeals, 17.7.2018 - No. 339737, 2018 WL 3443383 Estate of Horton

27. County court in Varaždin decision no. Gž- $1 / 20$

\section{WEBSITE REFERENCES}

1. Coronavirus and the Law in Europe, Intersentia online, available at: [https://www.intersentiaonline.com/bundle/coronavirus-and-the], accessed 12. March 2021

2. Croatian Notaries Chamber, available at: [https://www.hjk.hr/], Accessed 26 February 2021

3. e-Justice Expert Group, Interconnection of Registers of Wills, Final Report, available at: [https://e-justice.europa.eu/fileDownload.do?id=a40a5542-6765-4ad0-9f42-5b1dcf70acd5], Accessed 14 March 2021

4. European Centre for Disease Prevention and Control, Data on country response measures to COVID-19, available at: [https://www.ecdc.europa.eu/en/publications-data/downloaddata-response-measures-covid-19], Accessed 26 February 2021

5. European Commission, Comparative Table on COVID-19 Impact on Civil Proceedings, available at: [https://e-justice.europa.eu/fileDownload.do?id=f74aa89f-e4c7-4946-8e6e985b6b250473], Accessed 15 March 2021

6. European Network of Registers of Wills Association - Members list, available at: [http:// www.arert.eu/Members.html?lang=en], Accessed 12 February 2021 
7. FINA, Broj ovršenika koji nemaju dovoljno sredstava na računima za otplatu duga $i$ ukupni dug na dan 31.10.2020. i 18.11.2020., available at: [https:/www.fina.hr/-/broj-ovrsenikakoji-nemaju-dovoljno-sredstava-na-racunima-za-otplatu-duga-i-ukupni-dug], Accessed 14 March 2021

8. C RW Expert Group, Recommendations on Electronic Will Registration and Data Exchange, available at: [https://e-justice.europa.eu/fileDownload.do?id=6198a645-a2c54c39-b712-f24f93116935], Accessed 14 March 2021

9. Public notary register, available at: [https://www.hjk.hr/Uredi], Accessed 14 March 2021

10. the BBC, Coronavirus: Wills witnessed by video link to be made legal, available at: [https:// www.bbc.com/news/uk-53530228], Accessed 09 March 2021

11. UK Government, Guidance on making wills using video-conferencing, available at: [https:// www.gov.uk/guidance/guidance-on-making-wills-using-video-conferencing], Accessed 09 March 2021 